\title{
Size and Day-of-the-Week Effect in the Banking Industry: A Comparative Analysis Based on Economic Conditions
}

\author{
Srinivas Nippani ${ }^{1}$, Kenneth M. Washer ${ }^{2} \&$ N.R. Vasudeva Murthy ${ }^{2}$ \\ ${ }^{1}$ Department of Economics and Finance, College of Business and Entrepreneurship, Texas A\&M University - \\ Commerce, TX, USA \\ ${ }^{2}$ Economics and Finance, Creighton University, NE, USA \\ Correspondence: Srinivas Nippani, Professor of finance, Department of Economics and Finance, College of Business \\ and Entrepreneurship, Texas A\&M University - Commerce, Commerce, TX 75429, USA. Tel: 1-903-886-5678. \\ E-mail: Sri.Nippani@tamuc.edu
}

Received: February 22, 2013

Accepted: April 3, 2013

Online Published: June 24, 2013

doi:10.5430/ijfr.v4n3p1

URL: http://dx.doi.org/10.5430/ijfr.v4n3p1

\begin{abstract}
Several studies in empirical literature have examined the differences between large banks and small banks. In this study, we examine the differences in the day-of-the-week effects of stock prices of large banks as represented by the Keefe, Bruyette and Woods Index (KBW) and small banks as represented by the American Bankers Association NASDAQ Community Bank Index (ABAQ) in three successive economic periods: the pre-recession, recession and the post-recession. We find that the stock return movements of the two indices are similar to each other. Both the indices have very similar weekday effects in all three periods. We conclude that while there is more volatility in the KBW index, it is not reflected in any higher returns for larger bank shareholders. We further provide evidence that the ABAQ index and the KBW index levels are cointegrated which explains why the results on the returns appear so similar to each other.
\end{abstract}

Keywords: day-of-the-week effect, bank size

\section{Introduction}

There were 14,388 commercial banks in the United States in 1984. This total shrunk to 6,177 banks at the end of 2011 (Note 1). There has been a significant change in the composition of the industry over the past three decades. Most legislation passed in the 1990s was deregulatory in nature. This helped banks merge and consolidate across state boundaries initially and later legislation helped banks branch out into financial services areas that previously were closed to them. Most of these changes caused a change in the structure and operations of the banking industry. While several studies have examined the impact of these changes on large banks and their smaller counterparts and the results are mixed, no major study has looked at the differences in the day-of-the-week effects for large banks and their smaller counterparts. In the present study, we compare the performance of large bank stocks as represented by the Keefe, Bruyette and Woods Index (KBW hereafter) and small banks as represented by the American Bankers Association NASDAQ Community Bank Index (ABAQ hereafter). We find that the stock index movements of the two indices are surprisingly similar. Both indices have similar weekday effects in three separate periods; the pre-recession, recession and post-recession. While there is more volatility in the KBW index, it is not reflected in higher returns for larger bank shareholders. It is also shown that the levels of the two indices are cointegrated which may explain the returns being similar on several weekdays.

A large number of studies have been undertaken to examine the day-of-the-week effects in several major markets. Studies by Gibbons and Hess (1981) and Kiem and Stambaugh (1984) were among the first to point out that small firms showed greater weekend effects than large firms. Brusa, Liu and Schulman (2000) show a traditional weekend effect (with Monday returns being negative) for small firms and positive for large firms (reverse weekend effect). We examine if a similar difference exists between the largest banks and their smallest counterparts.

Over the past two decades, several studies have looked at bank size and its impact on the various aspects as measured by performance. Akhigbe and McNulty (2005) look at the profit efficiency of small, medium and large commercial banks for the period 1995 to 2001 and examine the sources of profit efficiency for each. They find that large and small banks have different ways of attaining higher profits. In another study, Carter, McNulty and Verbrugge (2004) find that after controlling for market concentration, cost of funds and several other factors that could impact yields, smaller banks earn greater risk-adjusted yields as compared with their larger counterparts. The authors argue that 
small banks make better choices because of their information advantage in evaluating credit. Toby (2006), states that smaller banks are more efficient than their larger counterparts in most countries.

In a recent study, Zou, Miller and Malamud (2011) examine the effects of geographical deregulation on commercial bank performance across states. They reach several conclusions. First, they report increased profitability and performance with higher returns and reduced riskiness. For their medium sized counterparts, it increased with deregulation. For larger banks, it either increased or decreased depending on the risk variable considered. They also report that macroeconomic variables affect bank performance as much if not more than the process of deregulation in the case of small and medium sized banks. Berger, Miller, Petersen, Rajan and Stein (2005) find that small banks being better able to collect and act on soft information than their larger counterparts. Interestingly, they also find that larger banks tend to lend at greater distance, are more impersonal to their borrowers and have shorter and less exclusive relationships and do not alleviate credit constraints as effectively.

Nippani and Washer (2005) studied the impact of Interstate Branching and Banking Efficiency Act (IBBEA) implementation on the relative profitability of small banks and find that small banks' return on assets was significantly less than their larger counterparts in the post-IBBEA period. This is contrary to the pre-IBBEA period. In an earlier study, Nippani and Green (2002) find that performance of banks in general improved in the post-IBBEA period but when controlled for general economic conditions and interest rate movements, the impact of the IBBEA appears insignificant.

In the popular press, there are several examples of articles that separate the performance of large banks from their smaller counterparts. In a three part article series depicting the latest performance of large banks, mid-size banks and community banks, Mambrino and Robin (2012b) mention several differences between large and community banks. They mention that while large banks recovered in 2011, community banks still faced obstacles like sluggish loan growth, and weaker revenues despite increased deposit growth. They also mention that increased regulatory and compliance costs added to lower profitability, increasing the pressure to consolidate. They mention that the future for community banking remains threatened by regulatory costs, challenges for finding talent, the movement of population towards urban areas and continued economic weakness. They mention that the top performers among community banks focused on agricultural lending. They were also helped by FDIC assisted acquisitions. In their article on large banks Mambrino and Robin (2012a) mention that these big institutions with assets over $\$ 10$ billion benefited from improved credit conditions. They looked to find businesses that generated non-interest income also. It appears from the authors' description in their research that the strengths of larger banks were not necessarily the same as was for their smaller counterparts.

Weidner (2012) argues in an article published in the Wall Street Journal that the number of applications to start new banks have come down drastically. He mentions "rather than mortally wound themselves, big, bailed-out banks actually benefited from their own failures. The new regulations they brought upon the entire U.S. banking industry are squeezing the smallest competitors and turning out our banking system into a commodity business." He also mentions "Ultimately, I see the demise of community banks as symptomatic of a bigger problem: a financial system where the biggest participants seem to win for losing. The more they consolidate, the more they struggle at managing their huge balance sheets and sprawling global operations. Yet their competitors are the ones who seem to pay the price." The sentiment about higher regulatory costs causing distress for smaller banks is also mentioned elsewhere.

McGrane (2012) discusses a routine conference call between bankers and regulators in the United States wherein some bankers representing community banks voiced concerns about regulators new rules with regard to capital rules following the signing of Basel III. She mentions "Small lenders say the elaborate Basel III system was designed to rein in large, internationally active banks that brought the financial system to its knees, not small community institutions." Smaller banks, according to the author could have trouble raising the extra capital since most of them do not have access to capital markets.

Based on the academic studies and in the popular press discussed above, it appears that there are significant differences between large banks and their smaller counterparts. Pearson (2010) provides evidence that suggests that community bank failures in 2009 hit a level not reached since the banking crisis of the 1980s and the early 1990s. He argues that much of the systemic risk in troubled community banks has been related to real estate lending activities. A study by Cornett, McNutt and Tehranian (2009) shows that while bank performance decreases dramatically during the crisis, the largest banks see the largest losses. They also find stronger relations between corporate governance changes and 2008 stock market returns for large banks than small banks.

Our motivation for this paper is based on all of the above studies. There appears to be significant differences in both the nature of business for large banks and their smaller counterparts. In fact, one seldom comes across an industry where there are so many larger and smaller participants with different strengths and performing similar functions in society. It would be interesting to see if these differences are reflected in a weekly pattern of their stock returns. If 
larger banks and their smaller counterparts are valued differently by the stock market, we would notice significant differences in their stock price movements based on the day-of-the-week similar to the results of Brusa, Liu and Schulman (2000). If this were not the case, we would notice that the stock price movements are similar for smaller banks and their larger counterparts.

In the next section, we discuss the data used in the study. We present our empirical evidence in section three followed by the conclusions and implications in the final section.

\section{Data}

Our sample period runs from December 8, 2003 until February 12, 2012. The start date coincides with the establishment of the community bank index (ABAQ) (Note 2). There are a total of 1,986 daily observations, and we eliminated trading days that followed holidays in order to make our work comparable to others. In regards to small banks, we use ABAQ. It includes NASDAQ listed banks and thrifts (or their holding companies) that are designated as banks by the Industry Classification Benchmark. The 50 largest banks or thrifts based on asset size are excluded. Our proxy for big banks is KBW bank index. We accessed data for the KBW index from Bloomberg Database. It consists of 24 money centered banks and leading regional institutions.

Both indexes are capitalization weighted and are calculated based on total return. According to the National Bureau of Economic Research, the recession occurred between December 1, 2006 and June 30, 2009. Based on this, we divide our data into three different time periods: the pre-recession period is from December 8, 2003 ending with November 30, 2006. The recession period is from December 1, 2006 to June 30, 2009; and the post-recession period is from July 1, 2009 to February 10, 2012.

\section{Empirical Evidence}

Table 1 displays descriptive statistics by day-of-the-week for KBW bank index and ABAQ bank index for the entire period. Monday, Thursday and Friday all had negative average returns, but the only significant one was Monday for community banks (at the $1 \%$ level). As seen from the results presented in Table 1 below, the returns on the two indices appear very similar. We conducted mean comparison tests and found that the daily returns were not significantly different for the two bank indexes over this entire period. This is true even of Monday returns where KBW returns are more negative and yet not statistically significant.

Table 1. Descriptive statistics and simple T-tests

\begin{tabular}{lccc}
\hline & ABAQ & KBW & Difference \\
\hline Monday & & & \\
Avg (\%) & $-0.17^{* *}$ & -0.27 & 0.10 \\
Std Dev (\%) & 1.94 & 3.23 & 1.70 \\
T-stat & -1.72 & -1.59 & 1.06 \\
N & 369 & 369 & 369 \\
Tuesday & & & \\
Avg (\%) & 0.12 & 0.15 & -0.03 \\
Std Dev (\%) & 1.83 & 2.92 & 1.50 \\
T-stat & 1.32 & 0.98 & -0.30 \\
N & 381 & 381 & 381 \\
Wednesday & & & -.04 \\
Avg (\%) & 0.03 & 0.07 & 1.30 \\
Std Dev (\%) & 1.69 & 2.59 & -0.75 \\
T-stat & 0.34 & 0.59 & 422 \\
N & 422 & 422 & \\
Thursday & & & 0.04 \\
Avg (\%) & -0.1 & -0.5 & 1.31 \\
Std Dev (\%) & 1.87 & 2.69 & 0.51 \\
T-stat & -0.16 & -0.36 & 414 \\
N & 414 & 414 & 0.03 \\
Friday & & & 1.05 \\
Avg (\%) & -0.03 & -0.06 & 0.61 \\
Std Dev (\%) & 1.47 & 2.05 & 400 \\
T-stat & -0.36 & -0.57 & \\
N & 400 & 400 & \\
\hline
\end{tabular}

*significant at the $5 \%$ level

**significant at the $10 \%$ level 
In all cases, money-centered banks had higher standard deviations than community banks with the most extreme volatility being on Monday. Figures 1 and 2 show the daily returns for both large banks (KBW) and community banks (ABAQ). Index returns are shown in Figures 3 and 4. Leading up to the recession, returns were relatively timid and then during the recession exploded (Note 3).

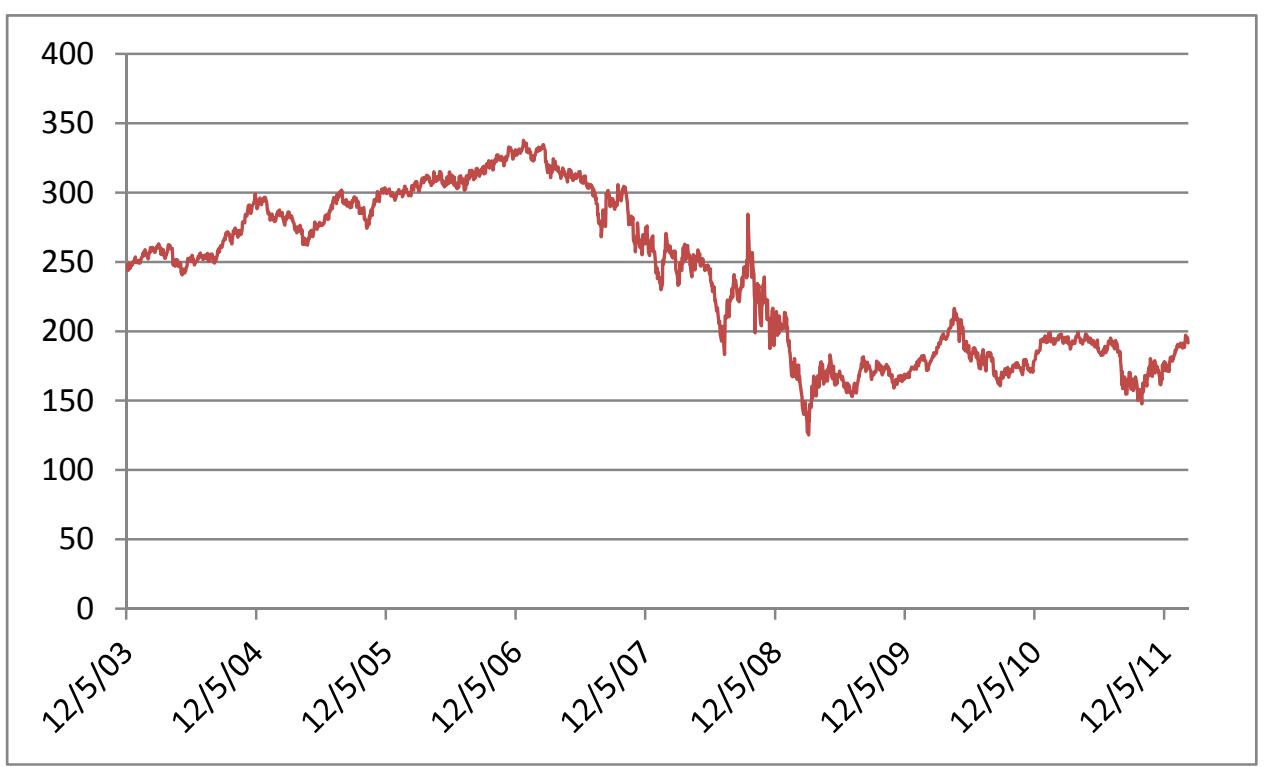

Figure 1. The price level for ABAQ Index (December 8, 2003-February 12, 2012)

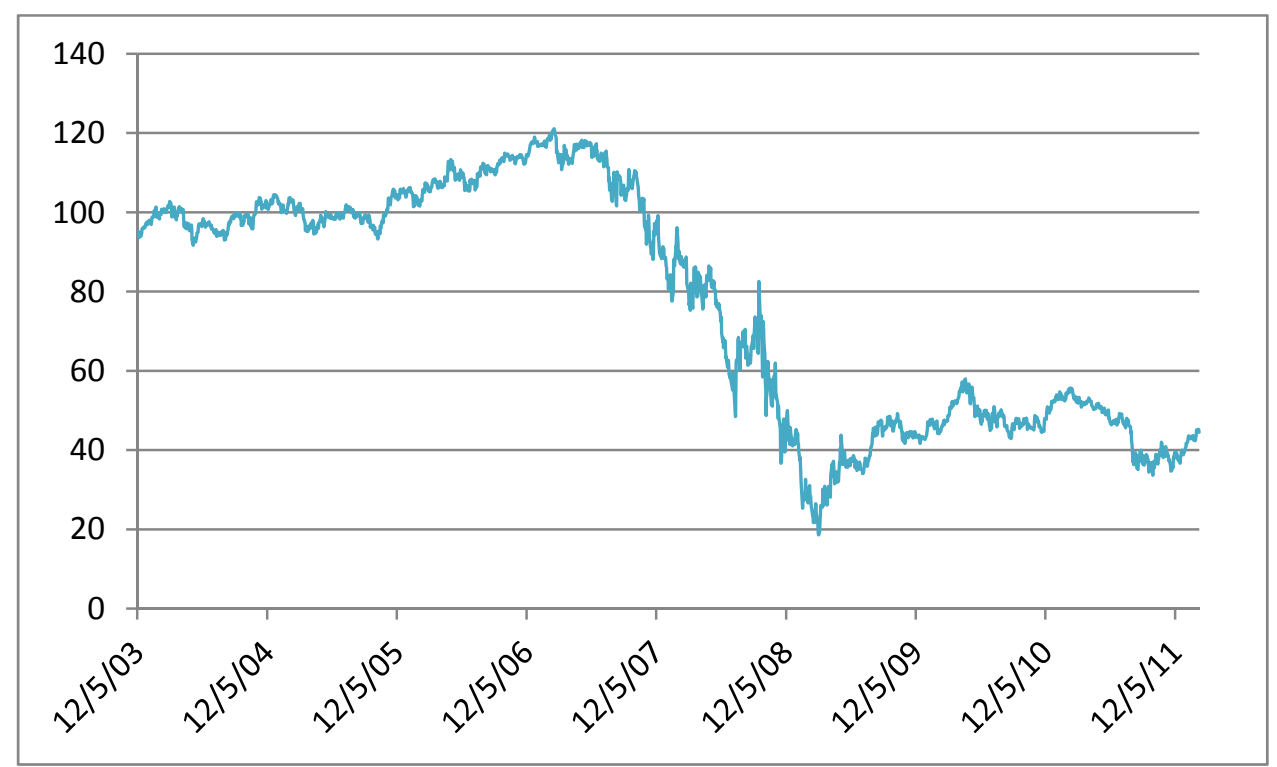

Figure 2. The price level for KBW Index (December 8, 2003-February 12, 2012) 


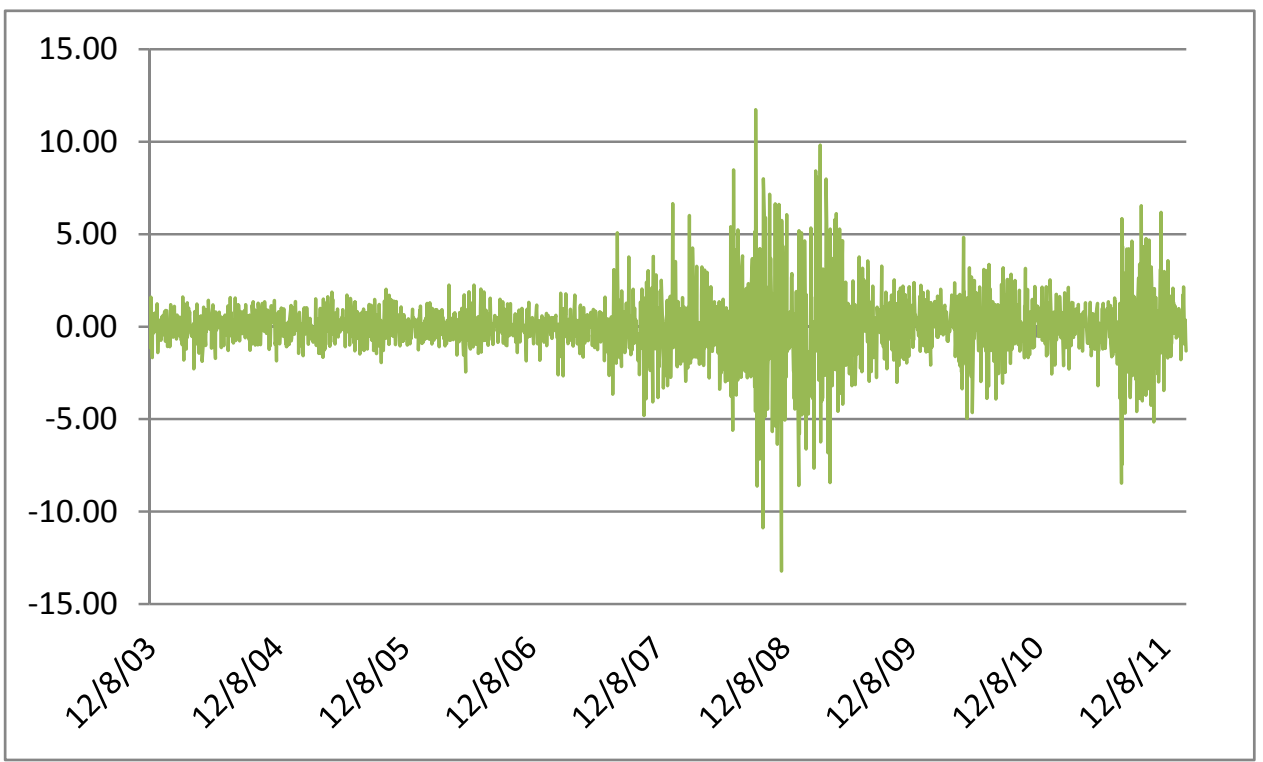

Figure 3. Daily returns for ABAQ Index (December 8, 2003-February 12, 2012)

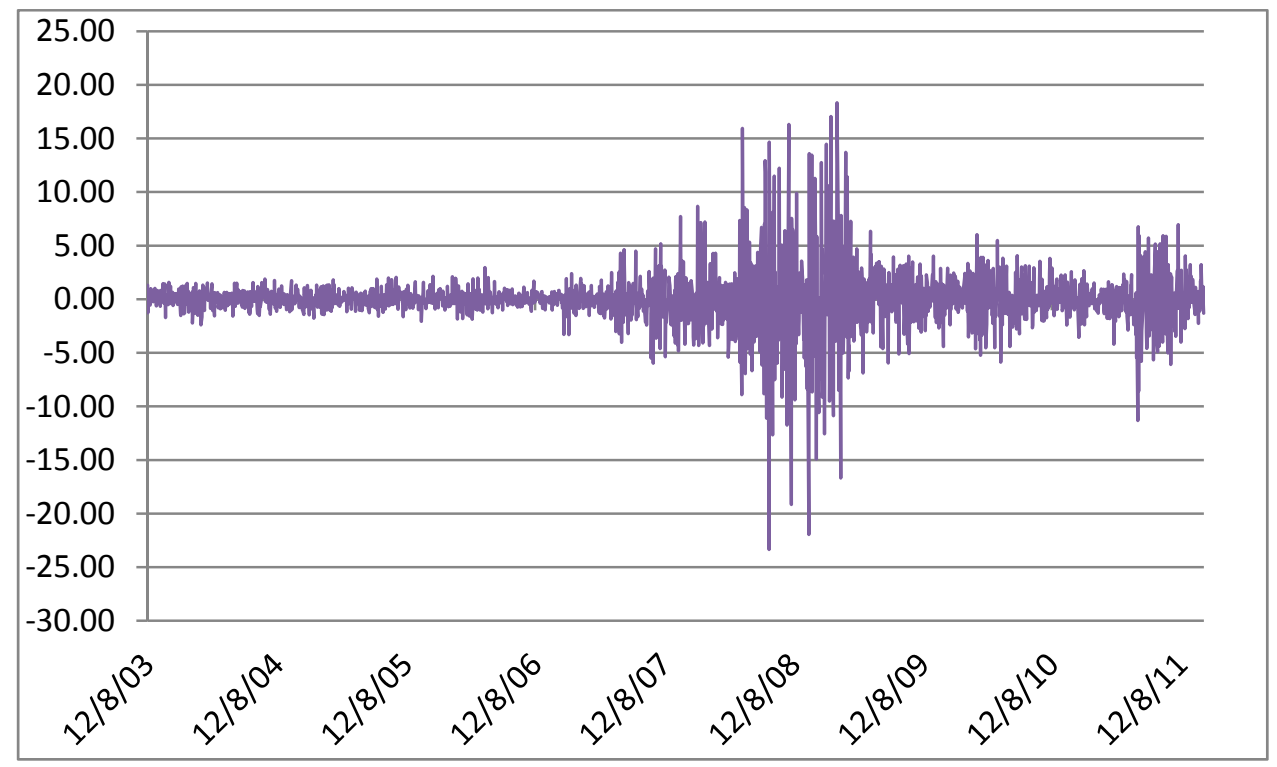

Figure 4. Daily returns for KBW Index (December 8, 2003-February 12, 2012)

As the Monday returns were negative for both indices, we examined to see if the returns on Monday were significantly different from other weekdays by examining for the day of the week effect.

\subsection{Day-of-the-Week Effects}

Equation 1 is employed to test statistically whether the daily returns are different according to the day-of-the-week. The continuously compounded daily return is represented by $r_{t}$. Dummy variables are included as independent variables and the associated beta coefficients $\left(b_{1-4}\right)$ measure the return difference between a particular day of the week and Monday.

$$
r_{t}=b_{0}+b_{1}(\text { Tues })+b_{2}(\text { Wed })+b_{3}(\text { Thurs })+b_{4}(\text { Fri })+e_{t}
$$

The t-statistics in the regression model used robust standard errors to correct for the presence of autocorrelation, which makes it much less likely to commit type 1 errors. 
Table 2. Day-of-the-week effects

\begin{tabular}{lcrrrrr}
\hline & $\begin{array}{c}\text { Pre-recession } \\
(\mathrm{n}=725)\end{array}$ & \multicolumn{2}{c}{$\begin{array}{c}\text { Recession } \\
(\mathrm{n}=624)\end{array}$} & \multicolumn{2}{c}{$\begin{array}{c}\text { Post-recession } \\
(\mathrm{n}=637)\end{array}$} \\
& Coef. Est. & $\mathrm{t}$-value & Coef. Est. & t-value & Coef. Est. & t-value \\
\hline$A B A Q$ & & & & & & \\
Intercept & 0.06 & 0.89 & -0.63 & $-2.47^{*}$ & 0.2 & 0.14 \\
Tuesday & -0.00 & -0.03 & 0.85 & $2.38^{*}$ & 0.09 & 0.40 \\
Wednesday & 0.02 & 0.16 & 0.52 & 1.61 & 0.08 & 0.37 \\
Thursday & -0.06 & -0.62 & 0.59 & $1.67^{* *}$ & -0.03 & -0.15 \\
Friday & -0.04 & -0.48 & 0.61 & $1.95^{* *}$ & -0.10 & -0.47 \\
$K B W$ & & & & & & \\
Intercept & 0.08 & 1.41 & -1.02 & $-2.18^{*}$ & 0.09 & 0.41 \\
Tuesday & -0.10 & -1.13 & 1.50 & $2.37^{*}$ & -0.09 & -0.32 \\
Wednesday & -0.02 & -0.22 & 1.00 & 1.72 & 0.07 & 0.27 \\
Thursday & -0.09 & -1.14 & .79 & 1.33 & -0.00 & -0.01 \\
Friday & -0.05 & -0.62 & .95 & $1.77^{* *}$ & -0.24 & -0.88 \\
\hline
\end{tabular}

*significant at the $5 \%$ level

**significant at the $10 \%$ level

Table 2 shows the results from the regression model. The small bank index is shown first (ABAQ) followed by the large bank index (KBW). We investigate three distinct periods, which are pre-recession, recession and post-recession. We find no day-of-the-week effects in either the Pre or Post-recession periods for either index. However, during the recessionary period, Monday's average returns were significantly different from zero and statistically different from returns on most other days of the week. The traditional weekend effect of negative Monday returns are manifested in the recession period for both the indices in the study. Tuesday appears to be a "bounce back" day as average returns are positive and different from Monday. The returns for Friday are positive and significant for both indices while the only major difference is that the returns for the small banks index are positive and significant for Thursdays during the recession unlike their larger counterparts. All results discussed above are statistically significant at the 5\% level. In addition to these, there are some very interesting patterns in the pre-recession and the post-recession periods. We find no single daily return that is significant for either of the indices. All five days of the week the returns are not significant statistically for both the KBW index and the ABAQ index. In order to further examine the differences during the three time periods, we conducted a paired comparison test for ABAQ index returns less the returns of the KBW index. The results of these tests are given in Table 3 below.

Table 3. Paired t-test ABAQ minus KBW

\begin{tabular}{lrrrrrr}
\hline & $\begin{array}{c}\text { Pre-Recession } \\
(\mathrm{n}=725)\end{array}$ & \multicolumn{2}{c}{$\begin{array}{c}\text { Recession } \\
(\mathrm{n}=624)\end{array}$} & \multicolumn{2}{c}{$\begin{array}{c}\text { Post Recession } \\
(\mathrm{n}=637)\end{array}$} \\
& Coef. Est. & $\mathrm{t}$-value & Coef. Est. & t-value & Coef. Est. & t-value \\
\hline Monday & -0.02 & -0.26 & 0.38 & $1.49^{* *}$ & -0.07 & -0.74 \\
Tuesday & 0.07 & 0.79 & -0.27 & -1.22 & 0.11 & 1.35 \\
Wednesday & 0.01 & 0.13 & -0.10 & -0.54 & -0.06 & -0.85 \\
Thursday & 0.02 & 0.20 & 0.19 & 1.03 & -0.10 & -1.15 \\
Friday & -0.01 & -0.15 & 0.04 & 0.27 & 0.08 & 1.08 \\
\hline
\end{tabular}

*significant at the $5 \%$ level

**significant at the $10 \%$ level

It appears that large banks' returns were more impacted than small banks during the recessionary period. For example, Monday's return was $-0.63 \%$ for small banks and $-1.02 \%$ for large banks. Alternatively, the bounce back on Tuesday was larger for big banks (1.50\% versus $0.85 \%)$. In Table 3, we show the results from two-sample mean comparison tests. We find that Monday was significantly worse for big banks during the recession. They underperformed small banks by an average of 38 basis points. Although the average return was higher on Tuesdays for big banks (outperformed by 27 basis points), the results were not significant at the $10 \%$ level.

Based on the results of Tables 1-3, it appears that there are very clear and similar patterns in the returns for KBW index and ABAQ index. Firstly, during the pre-recession period, there is no weekday effect in either of the two indices. Secondly, the pattern is significantly changed with negative Monday returns and positive Tuesday and 
Friday returns for both indices during the recessionary period. This is followed by no significant pattern in the post-recession period. In fact based on the results of Table 3, one can argue that there are no differences in the returns of the two indices except for one weekday during the recessionary period.

The implication from these results is that the stock markets do not significantly differentiate based on bank size. Larger banks and their smaller counterparts despite being significantly different in many ways, appear to be valued along similar lines by investors. If this were true, the levels of the two stock indices would be conintegrated. We therefore test for cointegration in the next subsection.

\subsection{Conintegration Analysis}

In order to statistically discern whether the time series on KBW (KBWPRICE) and ABAQ in levels do form a long-run link, a cointegration analysis is undertaken. The main requirement for a cointegration analysis is to determine the order of integration of the time series used in the analysis. Specifically, we have to empirically determine whether the series, KBWPRICE and ABAQ are non-stationary or stationary in levels or first differences. There is reasonable ground to expect this based on the return patterns seen in the section above and Figures 1-4. Stationarity in this context means that the mean and variance of the series do not depend on time. If the series are found to be nonstationary, that is their first two moments depend on time, then we can determine whether these series do form a long-run link (cointegration). Therefore, at the very outset, we conduct a battery of the most widely used unit root tests. The results of the unit root tests are reported in Table 4.

Table 4. Unit root test results

\begin{tabular}{lrrrrr}
\hline Series & \multicolumn{1}{c}{ ADF } & \multicolumn{1}{c}{ DF-GLS } & \multicolumn{1}{c}{ KPSS } & \multicolumn{1}{c}{$\mathrm{MZ}_{\mathrm{a}}$} & \multicolumn{1}{c}{$\mathrm{MZ}_{\mathrm{t}}$} \\
\hline ABAQ & -2.371 & -1.476 & 0.797 & -4.369 & -1.477 \\
KBWPRICE & $-2,020$ & -1.445 & 0.675 & -4.18 & -1.445 \\
$\Delta$ ABAQ & $-51.788^{*}$ & $-51.787^{*}$ & 0.123 & $-22.880^{*}$ & $-3.38^{* *}$ \\
$\Delta$ KBWPRICE & $-50.537^{*}$ & $-3.50^{*}$ & $0.146^{* *}$ & $-5.034^{* *}$ & -1.586
\end{tabular}

The asterisks *and $* *$ denote the statistical significance at the $1 \%$ and $10 \%$ levels, respectively, in rejecting the null-hypothesis. Optimal lags are selected based on the SBC criterion. The 1\%, critical value for the ADF unit root tests is -3.962 . The $1 \%, 5 \%$ and $10 \%$ critical values for MZ $\alpha$ and MZt are $-23.80,-17.30,14.20$ and $-3.42,-2.91$ and -2.62 , respectively. Deterministic terms include both the constant and time trend.

While the ADF, ADF-GLS, MZ $\alpha$ and MZt unit root tests state null hypothesis of the presence of a unit root (nonstationarity), the KPSS unit root maintains the null hypothesis of stationarity (no unit root). The MZ $\alpha$ and the MZt unit root tests developed by Ng and Perron (2001) and the ADF-GLS unit root test suggested by Elliot et al., (1996) are more efficient and modified unit root tests compared to the traditional ADF test. From the overall results of the unit root tests presented in Table 4, we fail to reject the null hypothesis of the presence of a unit root in both the KBWPRICE and ABAQ level series, thus they are characterized as nonstationary level series. For the first differenced KBWPRICE and ABAQ series, we reject the null hypothesis at the $1 \%$ level.

Since both the series are found to be nonstationary in levels, we investigate whether they together exhibit a long-run relationship (cointegration). Therefore, in Table 5, we present the results of the Phillips-Hansen (1990) FM-OLS cointegration test (Hereafter, the FM-OLS). The FM-OLS cointegration test is a residual based single equation procedure, developed by Phillips and Hansen (1990) that simultaneously corrects for the presence of endogeneity and serial correlation in the cointegration model. This cointegration estimator has been found to be efficient in small samples (Hargreaves, 1994).

Table 5. Phillips-Hansen FM-OLS cointegration test results

$$
\begin{aligned}
& \text { KBWPRICE }=-46.209+0.513 \text { ABAQ } \\
& \text { t-values }(-24.965 *) \quad(68.304 *) \\
& \text { ADF }(4)=-3.4473 * ; \text { Bartlett Window Lag Length }=8
\end{aligned}
$$

*From the ADF unit root test results on the residuals from the FM-OLS cointegration equation, shown in Table 5, we note that the series KBWPRICE and ABAQ are cointegrated. Thus, in the long-run these two nonstationary series do form a link. The intercept and coefficient of ABAQ with a positive sign are statistically significant at the $1 \%$ level.

We can see from the ADF unit root test results on the residuals from the FM-OLS cointegration equation, shown in Table 5, that the series KBWPRICE and ABAQ are cointegrated. Thus, in the long-run these two nonstationary series do form a link. The coefficient of ABAQ, with a positive sign, is statistically significant at the $1 \%$ level. We discuss the implications of our results in the next section. 


\section{Implications and Conclusion}

Numerous studies have examined the differences between large banks and their smaller counterparts over the past decade. While Akhigbe and McNulty (2005) show that larger and smaller banks have different ways of attaining higher profits, Carter et. al., (2004) show that smaller banks earn greater risk adjusted returns than larger banks. Berger et. al. (2005) show that small banks are better able to collect and act on soft information while Nippani and Washer (2005) showed that smaller banks are less profitable in the post-IBBEA period. These results in academic studies are supported by several articles and opinions in the popular press that showed that smaller banks appear to have distinct disadvantages both in recovering from the recession and in meeting the greater costs that are required as a result of increased monitoring by regulators.

Other studies, notably by Brusa et. al. (2000) show there exists a size effect in the market. Based on these studies, we examine to see if the market values larger banks and their smaller counterparts differently on different weekdays. Our results first suggested that the daily return patterns of both large banks and community banks are very similar when taken during the pre-recession, recession and post-recession periods. Both indices show very similar weekday effects in all three periods, which indicated the possibility that their levels could be cointegrated. We examined cointegration and found that these two index levels were cointegrated. We conclude that despite their many differences, stock markets appear to view banks' stocks similarly.

Our results have several implications. Firstly, this is the first study to examine the stock market differences in returns between the largest banks and their smallest counterparts. Considering the many differences in the way they conduct business and the way they earn their income, there appears to be no significant difference in apparent shareholder returns for the two sets of institutions. Secondly, there has been considerable consolidation in the banking industry both due to the changes in laws (IBBEA 1994 and the Financial Services Modernization Act of 1999) and the recent recession. The study shows that despite the comparative advantages bestowed on larger banks by these acts, smaller bank stockholders are not worse off compared with the stockholders of larger banks over the past decade. This is a very interesting finding in itself. This could lead to implications for stock managers and individual stockholders alike.

Smaller banks despite their apparent disadvantages may not be bad investments and may in fact be a good source of investment for portfolio managers due to their lower volatility without a significant compromise on return. It is also noticeable that unlike other institutions, portfolio managers may have to follow a different pattern of weekend trading strategies to profit in case of banks. In regards to the ongoing discussion between General Motors and the government in the popular press about buying back shares sold to the government, Bennett and Terlep (2012) mention "The government says it has already made a profit on the emergency funds injected into banks at the time of the financial-industry bailout. The Treasury has so far collected \$264.7 billion after investing \$245 billion in more than 700 banks". Based on this statement it is obvious that the industry has fared better comparatively and offers good potential for portfolio managers looking for profit seeking alternatives. The knowledge of the day of the week effects would help portfolio managers time their purchases better. This is a good source of investment for longer term investors looking for stock investments.

The study also has implications for short term investors who trade based on market timing and volatility. The study shows that the best opportunity for volatility investing is with larger banking institutions especially during a recession. Short term investors can better time the market by going long (or short when it is appropriate) and make gains based on market momentum.

Finally, this is the first study that shows that banking index levels of at least two indices representing the largest and the smallest listed banks are cointegrated. Future studies can look into whether this is true of all bank indices. Our study is limited by the fact that the availability of data on the smallest of listed banks (ABAQ) started only in 2003. This study could be replicated in the future during more stable economic conditions to examine the similarities and dissimilarities in performance of banks based on bank size.

\section{Acknowledgement}

We thank Martins B. Oguntunde and Huan (Alicia) Guo for graduate assistantship. We also thank anonymous IJFR referees and participants of the Southwestern Finance Association Meetings, March 2013 for valuable suggestions. Any remaining errors are ours.

\section{References}

Akhigbe, A., \& McNulty, J. (2005). Profit Efficiency sources and differences among small and large U.S.Commercial Banks. Journal of Economics and Finance, 29(3), 289-299. http://dx.doi.org/10.1016/j.jeconbus.2011.07.001

Bennett, J., \& Terlep, S. (2012, September 17). U.S. Balks at GM Plan: Government is Reluctant to Sell Auto Stake at a huge loss. Wall Street Journal, A1-A2. 
Berger, A., Miller, N. H., Petersen, M. A., Rajan, R. G., \& Stein, J.C. (2005). Does function follow organization form? Evidence from the lending practices of large and small banks. Journal of Financial Economics, 76(2), 237-269. http://dx.doi.org/10.1016/j.jfineco.2004.06.003

Brusa, J., Liu, P., \& Schulman, C. (2000, June/July). The Weekend Effect, 'Reverse' Weekend Effect and Firm Size. Journal of Business Finance \& Accounting, 27(5) \& (6), 555-574.

Carter, D.A., McNulty, J.E., \& Verbrugge, J.A. (2004). Do Small Banks have an Advantage in Lending? An Examination of Risk Adjusted Yields on Business Loans at Large and Small Banks. Journal of Financial Services Research, 25(2/30), 233-252. http://dx.doi.org/10.1023/B:FINA.0000020663.21079.d2

Cornett, M. M., McNutt, J. J., \& Tehranian, H. (2009). The Financial crisis, Internal Corporate Governance, and the Performance of Publicly- Traded U.S Bank Holding Companies. SSRN Working Paper Series.

Elliot, G., Rothenberg, T., \& Stock, J. (1996). Efficient tests for an autoregressive unit root, Econometrica, 64, 813-36. http://dx.doi.org/10.2307/2171846

FRED database of the Federal Reserve Bank of St. Louis. Retrieved from http://research.stlouisfed.org/fred2/data/USNUM.txt

Gibbons, M., \& Hess, P. (1981). Day-of-the-Week Effects in Asset Returns. Journal of Business, 579-96. http://dx.doi.org/10.1086/296147

Hargreaves, C.P. (1994). Non-Stationary Time Series, Analysis and Cointegration. Oxford University Press, Oxford.

Keim, D., \& Stambaugh, R. (1984, July). A further investigation of the Weekend Effect in Stock Retuns. Journal of Finance, 819-35. http://dx.doi.org/10.1111/j.1540-6261.1984.tb03675.x

Mambrino, V., \& Robin, N. (2012a). Top performing Big Banks. American Bankers Association, 104(4), 36-39.

Mambrino, V., \& Robin, N. (2012b). Top performing Community Banks. American Bankers Association, 104(6), $36-40$.

McGrane, V. (2012). Small Banks Are Blunt in Dislike of New Rules. The Wall Street Journal, 1-2.

Ng, S., \& Perron, P. (2001). Lag length selection and the construction of unit root tests with good size and power. Econometrica, 69, 1519-54. http://dx.doi.org/10.1111/1468-0262.00256

Nippani, S., \& Green, K. W. (2002). The banking industry after the Riegle-Neal Act: Re-structure and overall performance .Quarterly Review of Economics and Finance, 42(5), 901-909. http://dx.doi.org/10.1016/S1062-9769(01)00106-5

Nippani, S., \& Washer, K. M. (2005). IBBEA Implementation and the relative profitability of small banks. American Journal of Business, 20(2), 21-24. http://dx.doi.org/10.1108/19355181200500008

Pearson, V. (2010). Community Banks in Crisis: How They Got In and How They'll Get Out. The RMA Journal, 92(8), 26-30, 11.

Phillips, P.C.B., \& Hansen B.E. (1990). Statistical Inference in Instrumental Variable Regression with I (1) Process. Review of Economic Studies, 58, 407-436. http://dx.doi.org/10.2307/2298004

Toby, A.J. (2006). Methodological Approach to the study of x-efficiencies and scale economies in banking: Are smaller banks more efficient than larger banks? Journal of Financial Management \& Analysis, 19(2), 85-96.

Weidner, D. (2012). Who wants to start a Bank? No one. The Wall Street Journal, 1-2.

Zou, Y., Miller, S, M., \& Malamud, B. (2011). Geographic deregulation and commercial bank performance in U.S. state banking markets. Quarterly Review of Economics and Finance, 51(1), 28. http://dx.doi.org/10.1016/j.qref.2010.09.003

\section{Notes}

Note 1. Source: FRED database of the Federal Reserve Bank of St. Louis: http://research.stlouisfed.org/fred2/data/USNUM.txt

Note 2. We thank Helen Sullivan of American Bankers Association and Claude Courbois and his colleagues at Economic and Statistical Research, NASDAQ OMX group for providing us with the daily data of the ABA Banking index.

Note 3. In a two-sample variance comparison test (the results of which are not reported here) we found that over the entire period, the variance of returns associated with money-centered banks (KBW) was significantly higher than that of community banks (ABAQ) at the $1 \%$ level. The variances were statistically different by day of the week and also over the recessionary and non-recessionary periods. 